\title{
Length-Weight Relationship and Growth of a Marine Gastropod Mollusk, Hemifusus ternatanus (Gmelin) (Family: Melongenidae)
}

\author{
Shougou Yang ${ }^{1}$, Fen Cheng ${ }^{1}$, Xiangyu Wu ${ }^{1}$, YiXuan Xing ${ }^{1}$, ZhiFeng Gu$^{2}$ and \\ Xianming Tang ${ }^{1, *}$ \\ ${ }^{1}$ Hainan Academy of Marine and Fisheries science of China, Hai Kou 571126, \\ PR China \\ ${ }^{2}$ Ocean College, Hainan University, 58 Renmin Avenue, Haikou 570228, Hainan, \\ PR China
}

\section{A B S T R A C T}

Length-weight relationship and growth of a marine gastropod mollusk, Hemifusus ternatanus was studied for 36 months under artificial condition. The total shell length (SL), shell width (SW) and total weight (TW) were measured for eight times throughout the experimental period. The length-weight relationship can be expressed as $W t=0.0734 \times S L^{2.7817}\left(R^{2}=0.9924\right)$ and width-weight can be expressed as $W t=$ $0.5763 \times S W^{3.036}\left(R^{2}=0.974\right)$. The correlation coefficients between morphometric traits and total weight reached the significant level. With the increasing of animal age, the growth of total shell length, width and weight significantly increased, while the growth rate decreased with the increasing of animal age. Results from the present study provide the first biological reference to $H$. ternatanus and are useful for assessing the growth and resource assessment of $H$. ternatanus.
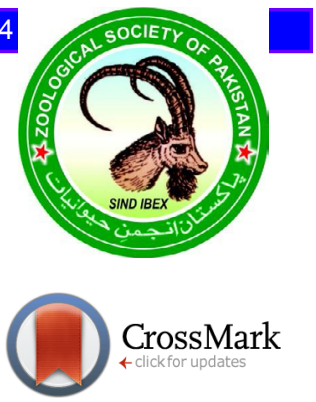

\begin{tabular}{l} 
Article Information \\
\hline Received 20 August 2018 \\
Revised 14 December 2018 \\
Accepted 27 January 2019 \\
Available online 14 September 2020 \\
Authors' Contribution \\
SY designed and implemented the \\
experiment. FC wrote the manuscript. \\
XW and YX did breeding management \\
and assisted in measurement. ZG \\
analysed te data. XT provided project \\
support and experimental guidance. \\
Key words \\
Hemifusus ternatanus, Length-weight \\
relationship, Growth trait, Whelk, \\
Marine gastropod mollusk.
\end{tabular}

\section{INTRODUCTION}

$H$ emifusus ternatanus (Gmelin) belonging to the family Melongenidae of Galeodidae is a large predatory marine gastropod. It is widely distributed in southeast coast of China, Thailand, Singapore (Chan, 2009), Malaysia (Vermeij and Raven, 2009) and Japan (Phillips and Depledge, 1986). H. ternatanus is found in the Subtidal deep water zone at a depth of 10-70 $\mathrm{m}$ (Phillips and Depledge, 1986; Xu et al., 2006) and is usually captured by human. Due to overfishing and deterioration, the natural availability of $H$. ternatanus has reduced significantly, increasing the importance of artificial breeding and aquaculture of this species (Xu et al., 2006).

In addition, morphological variation always to assess the population differences in aquatic organisms and is recognized by one of the basic characteristics. Measurement, description and analysis of the morphological variations are basic steps to know questions of biological adaptability (Ge and Hong, 1995). The length-weight relationships can be used to calculate the condition index of selected species as well as to compare the life history and morphological difference between populations from

\footnotetext{
* Corresponding author: hn.tangxm@aliyun.com 0030-9923/2020/0006-2293 \$ 9.00/0

Copyright 2020 Zoological Society of Pakistan
}

different regions (Petrakis and Stergiou, 1995; Nie et al., 2013). H. ternatanus is commercially important whelks in China (Xu et al., 2006). Length, width and weight are the basic components over the biology of species at the individual and population levels. Information on lengthweight relationship and growth is essential for proper assessment and management of these whelks.

The length-weight relationship of $H$. ternatanus under artificial rearing condition is rare. In this study, the morphological structures of $H$. ternatanus including the shell length (SL), shell width (SW) and total weight (TW) were measured for eight times during rearing period. The aim of this study was to determine the phenotypic characteristics and total weight for H. ternatanus. Results from the present study will improve our understanding on the changes of the characteristics and the growth rate of $H$. ternatanus, and will also provide biological information on conserving the natural resource of these species in South China Sea.

\section{MATERIALS AND METHODS}

\section{Animal}

0-day post hatching $H$. ternatanus larvae were obtained from local hatchery, and were continually cultured 36 months in Hainan Fisheries Research Institute. During the culture period, the seawater temperature ranged from $17^{\circ} \mathrm{C}$ in winter to $33^{\circ} \mathrm{C}$ and the salinity varied between 
$25 \%$ and $31 \%$. The whelks were fed live Meretrix meretrix once a day (8:00 p.m.). Daily food consumption was approximately $6 \%-8 \%$ of total body weight. The residual diets were removed timely to prevent decomposition. The total shell length, shell width and total weight of the juveniles were frequently measured.

The shell length and width were measured by Vernier Calipers (accurate to $0.02 \mathrm{~mm}$ ), and the total weight were measured using an electronic balance (Mettler ME204E, Switzerland) to the nearest $0.1 \mathrm{mg}$. In the process of experiment and cultivation, feeding and recording temperature, salt, bait and growth were recorded regularly. In each sampling point, a total of 60 animals were randomly collected for measurement.

Table I.- Parameters of growth trait for $\boldsymbol{H}$. ternatanus.

\begin{tabular}{|c|c|c|c|c|c|}
\hline Month & $\begin{array}{l}\text { Growth } \\
\text { trait }\end{array}$ & Mean \pm SD & Sk & Kur & $\begin{array}{l}\text { CV } \\
(\%)\end{array}$ \\
\hline \multirow[t]{3}{*}{ One } & TW & $0.159 \pm 0.041$ & 0.40 & -0.73 & 26.13 \\
\hline & SL & $1.361 \pm 0.172$ & 0.78 & 1.01 & 12.65 \\
\hline & SW & $0.640 \pm 0.072$ & 0.62 & 0.04 & 11.30 \\
\hline \multirow[t]{3}{*}{ Two } & TW & $0.612 \pm 0.167$ & 0.91 & 1.15 & 27.27 \\
\hline & SL & $2.143 \pm 0.241$ & 0.43 & -0.16 & 11.26 \\
\hline & SW & $0.992 \pm 0.099$ & 0.23 & -0.36 & 9.96 \\
\hline \multirow[t]{3}{*}{ Three } & TW & $2.254 \pm 0.385$ & 0.84 & 1.12 & 17.07 \\
\hline & SL & $3.548 \pm 0.226$ & 0.55 & 0.48 & 6.36 \\
\hline & SW & $1.577 \pm 0.091$ & 0.53 & 0.89 & 5.76 \\
\hline \multirow[t]{3}{*}{ Four } & TW & $6.674 \pm 1.349$ & 0.33 & -0.40 & 20.21 \\
\hline & SL & $5.036 \pm 0.423$ & 0.08 & 0.04 & 8.40 \\
\hline & SW & $2.196 \pm 0.156$ & 0.23 & -0.48 & 7.09 \\
\hline \multirow[t]{3}{*}{ Twelve } & TW & $38.640 \pm 11.570$ & 0.70 & 0.69 & 29.93 \\
\hline & SL & $9.417 \pm 1.059$ & 0.18 & -0.23 & 11.24 \\
\hline & SW & $4.080 \pm 0.384$ & -0.34 & -0.84 & 9.40 \\
\hline \multirow[t]{3}{*}{ Fourteen } & TW & $54.670 \pm 16.900$ & 0.38 & -0.62 & 30.92 \\
\hline & SL & $9.359 \pm 1.985$ & -0.55 & -0.19 & 21.21 \\
\hline & SW & $3.850 \pm 0.480$ & 0.18 & -0.65 & 12.46 \\
\hline \multirow[t]{3}{*}{ Thirty-one } & TW & $135.280 \pm 26.670$ & 1.61 & 3.08 & 19.72 \\
\hline & SL & $13.647 \pm 0.890$ & 2.65 & 10.62 & 6.52 \\
\hline & SW & $5.573 \pm 0.442$ & 1.05 & 1.96 & 7.94 \\
\hline \multirow[t]{3}{*}{ Thirty-six } & TW & $207.950 \pm 23.470$ & 0.14 & -0.54 & 11.29 \\
\hline & SL & $16.104 \pm 1.303$ & -0.27 & -1.02 & 8.09 \\
\hline & SW & $6.656 \pm 0.834$ & -0.51 & -0.91 & 12.53 \\
\hline
\end{tabular}

SL, shell length; SW, shell width; TW, total weight, Sk, Skewness; Kur, Kurtosis.

The descriptive statistics of growth trait and morphometric relationships of total weight-length, weightwidth were analyzed by statistical software DPS 16.5. The relationship between total shell length (SL) and total weight (TW) and total shell width (SW) were calculated by the power regression $\mathrm{Y}=\mathrm{a} \times \mathrm{X}^{\mathrm{b}}$, where $\mathrm{Y}$ can represent as wet weight $(\mathrm{g}), \mathrm{X}$ was the total shell width $(\mathrm{cm})$, length $(\mathrm{cm})$ of the whelks, and b was the value obtained from the traits relationship. Being isometric when $b=3$ and allometric when this is not the case (positive if $b>3$, negative if $b<$ 3 ). The association degree of traits was calculated by the determination coefficient $\left(\mathrm{R}^{2}\right)$.

\section{RESULTS AND DISCUSSION}

Measured by the estimated value of growth trait and correlation coefficients

The present study aimed to assess the morphological variations under 36 month between individuals of $H$. ternatanus. The descriptive statistic includes, mean, standard error, skewness, kurtosis and coefficients of variation (CVs) of total shell length, width, weight were shown in Table I. The coefficients of variation of most measured total weight, range from $11.29 \%$ to $30.92 \%$, were higher than shell length and width. The CV of shell length was $6.36 \%-21.21 \%$ and the CV of shell width was relatively low $(5.76 \%-12.53 \%)$ which may suggest that a less potential for selection. Previous study indicates that was proved by low values of coefficient of variation (CV $<20 \%$ ) for measured variables and may justified high inheritability (Mamuris et al., 1998; Ferrito et al., 2007; Konan et al., 2010).

Observed the standard error of the growth traits were low and the skewness bias values were all close to 0 , indicating that the sampling data are suitable for the normal distribution. The correlation coefficient of growth traits was shown in Table II. The correlation coefficients of all growth traits were reached a highly significant level $(P<0.01)$, and all the data were expressed positively correlated in Table II.

Table II.- Correlation coefficients between traits and time of H. ternatanus.

\begin{tabular}{lccccc}
\hline CC & Time & SL & SW & TW & P-value \\
\hline Time & 1.000 & 0.958 & 0.952 & 0.913 & 0.0015 \\
SL & 0.958 & 1.000 & 0.999 & 0.929 & 0.0008 \\
SW & 0.952 & 0.999 & 1.000 & 0.927 & 0.0009 \\
TW & 0.913 & 0.929 & 0.927 & 1.000 & 0.0000 \\
\hline
\end{tabular}

$\mathrm{CC}$, Correlation coefficients; SL, shell length; SW, shell width; TW, total weight.

Length-weight and width-weight relationship of $\mathrm{H}$. ternatanus

At hatching, the mean shell length, shell width and total weight were $0.45 \mathrm{~cm}, 0.25 \mathrm{~cm}$ and $0.01 \mathrm{~g}$, respectively. The feeding activity was observed upon hatching. 
Previous study reported that the total shell length of newly hatched $H$. ternatanus was $0.7 \mathrm{~cm}$ (Amio, 1963) and 0.6 $\mathrm{cm}$ (Hamada, 1974). In the present study, the total shell length was slightly lower $(0.45-0.5 \mathrm{~cm})$, which may be due to the geographic difference, but was close to the Tang et al. (2012)'s findings $(0.342-0.604 \mathrm{~cm})$.

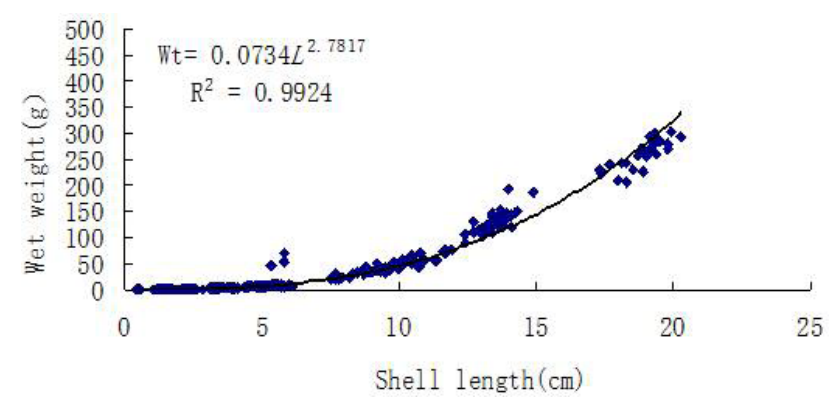

Fig. 1. Length-weight relationship of $H$. ternatanus $(n=762)$.

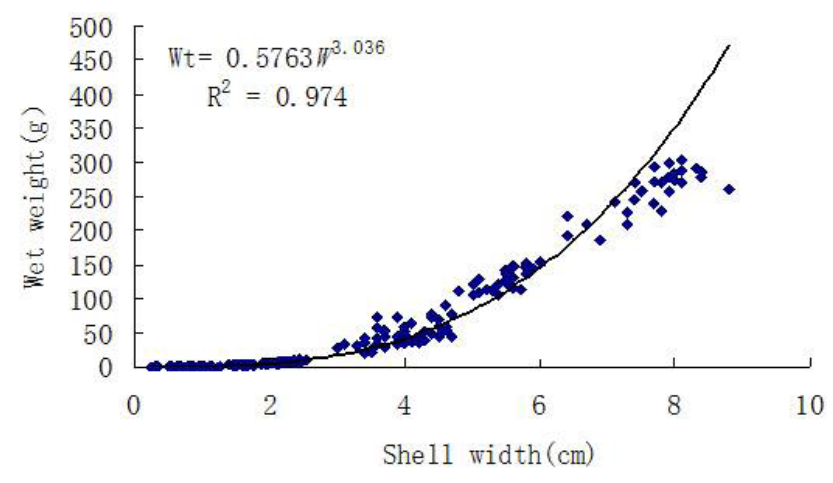

Fig. 2. Width-weight relationship of H. ternatanus $(n=762)$.

The shell width of whelks measured in this study varied from 0.25 to $8.8 \mathrm{~cm}$, and the total weight followed into the range of 0.01 to $239.4 \mathrm{~g}$ (Fig. 2). As the shell length increased, the total weight also increased, rendering a perfect power function relationship ( $n=762$, Fig. 1). The length-weight relationship of whelks can be derived as $W t=0.0734 \times S L^{2.7817}\left(\mathrm{R}^{2}=0.9924\right.$, Fig. 1), while the Width-weight relationship of whelks was expressed as $W t$ $=0.5763 \times S W^{3.036}\left(\mathrm{R}^{2}=0.974\right.$, Fig. 2$)$. The value of $b<$ 3 , obtained in the present study indicates that the growth of $H$. ternatanus cultured in artificial condition follows negative allometric trend. This result is consistent with studies on relationship of shell length and total weight for H. ternatanus. The growth of whelk collected from both Taiwan and Hainan follow negative allometric trend though the $b$ value differed slightly (Tang et al., 2016). The value of $b=3.036$, obtained in the present study indicate that the growth of $H$. ternatanus cultured in artificial condition follow the isometric. Despite the growth patterns exhibited the difference during different stage, the overall combined samples exhibited an isometric growth pattern through the 36-months rearing period. The parameters of biometric relationships, particularly $b$ value, which does not vary significantly throughout the year, unlike the parameter $a$ value, may vary daily, seasonally, and/or between habitats (Bagenal and Tesch, 1978). It is well known that temporal changes biometric relationship was strongly correlated with variations in the environment and different species. For example, during different life stages, the author Obirikorang et al. (2013) reported that the freshwater clam (Galatea paradoxa) exhibited an isometric growth was similar with by Ofori-Danson and Amoah (2007) revealed that the bivalve in its natural habitat exhibits an isometric growth pattern in the same location.

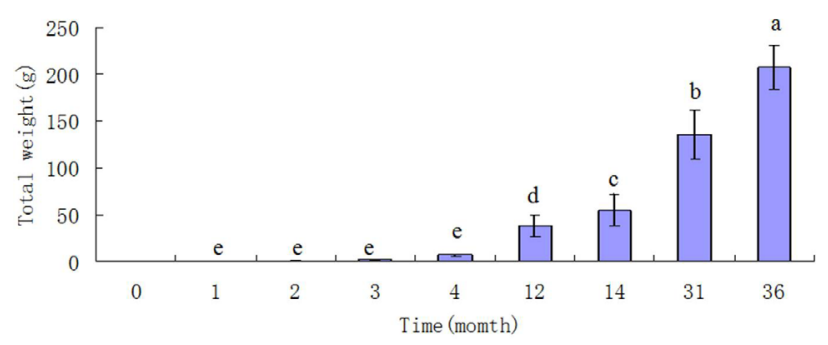

Fig. 3. Mean total weight of $H$. ternatanus hatchings fed M. meretrix for 36 month $(n=762)$. Data represent mean values \pm standard deviation (SD) for eighty-four samples $(\mathrm{n}=84)$. Error bars represent standard calculated margins of error. Different superscripts identify differences $(\mathrm{P}<$ $0.05)$.

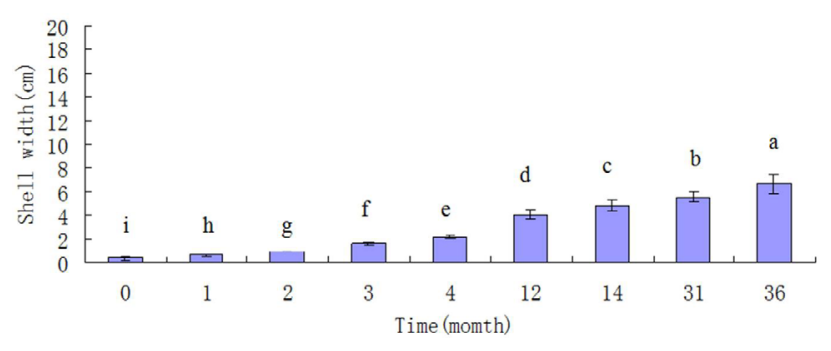

Fig. 4. Mean shell length of $H$. ternatanus hatchings fed M. meretrix for 36 month $(n=762)$. Data represent mean values \pm standard deviation (SD) for eighty-four samples $(n=84)$. Error bars represent standard calculated margins of error. Different superscripts identify differences $(\mathrm{P}<$ $0.05)$

Growth trait of $\mathrm{H}$. ternatanus

During the rearing period, the animals were continuously fed live Meretrix meretrix for 36 months. The shell length observed in the present study ranged 
from 0.45 to $18.2 \mathrm{~cm}$ with the wet weight ranging from 0.01 to $239.4 \mathrm{~g}$, and the shell width measured in this study varied from 0.25 to $7.7 \mathrm{~cm}$ in the rearing period (Figs. 3, $4,5)$. Compared with the shell weight and shell length, the relationship between shell width and time was closer to straight line (Figs. 3, 4, 5). With the increasing of age, the growth rates of shell length, width and weight were significantly different $(P<0.05$, Figs. $3,4,5)$. The growth rate includes the shell length, shell width and total wet weight decreased with the increasing of rearing period. Juveniles grew dramatically from $0.49 \mathrm{~cm}$ to $9.42 \mathrm{~cm}$ and $0.013 \mathrm{~g}$ to $38.64 \mathrm{~g}$ in first 12 months, followed by a period of reduced growth rate from 12 months to 36 months (Figs. 3, 4). In $H$. tuba juveniles, growth increased dramatically from $0.055 \mathrm{~cm}$ to $2.87 \mathrm{~cm}$ in 10 weeks, followed by a period of reduced growth rate (Morton, 1986a). Within 12 weeks, the shell length of $D$. orbita juveniles increased $6.95 \mathrm{~mm}$ at $18^{\circ} \mathrm{C}$ (Woodcock and Benkendorff, 2008). Similar results have been reported Tang et al. (2016) suggesting that the juveniles grow faster than the sub-adults of the rate of shell growth in $H$. ternatanu after the 56th week. With age, the biometric relationships undergo change, such information is vital for the management of aquaculture industry. Thus, H. ternatanus is more suitable for aquaculture better than other gastropods that deeming its relatively faster growth rate up to the market size.

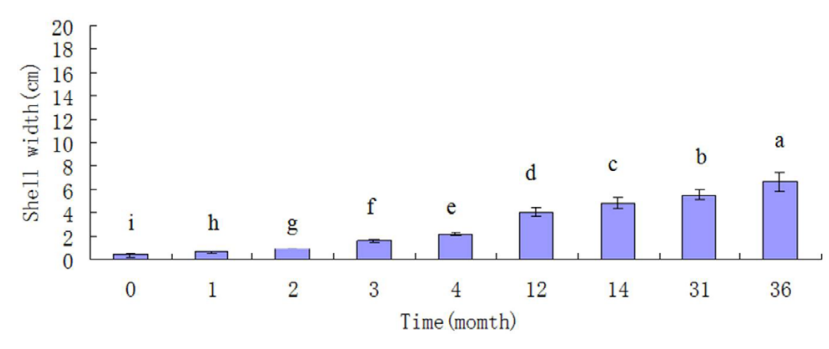

Fig. 5. Mean shell width of $H$. ternatanus hatchings fed M. meretrix for 36 month $(n=762)$; Data represent mean values \pm standard deviation (SD) for eighty-four samples $(\mathrm{n}=84)$; Error bars represent standard calculated margins of error; Different superscripts identify differences $(\mathrm{P}<$ $0.05)$.

\section{CONCLUSIONS}

In this study, length-weight relationship, widthweight relationship and growth of $H$. ternatanus were estimated for 36 months under artificial condition. This study has demonstrated that length-weight relationship can be expressed as $W t=0.0734 \times S L^{2.7817}\left(\mathrm{R}^{2}=0.9924\right)$ and width-weight can be expressed as $W t=0.5763 \times S W^{3.036}\left(\mathrm{R}^{2}=\right.$ $0.974)$. The correlation coefficients between morphometric traits and total weight all reached significant level $(P<$
0.01). The growth rate decreased with the increasing of rearing period. Our study provides biological reference to this species, and the results will provide fundamental information for resource assessment as well as for taking up further aquaculture practices of this species. $H$. ternatanus is more suitable for aquaculture better than other gastropods that deeming its relatively faster growth rate up to the market size.

\section{ACKNOWLEDGMENTS}

This study was supported by Public Science and Technology Research Funds Projects of Ocean (Grant No. 201405020), Hainan Academy of Marine and Fisheries science of China.

\section{Statement of conflict of interest}

The authors declare that there is no conflict of interests regarding the publication of this article.

\section{REFERENCES}

Amio, M.A., 1963. A comparative embryology of marine gastropods, with ecological emphasis. $J$. Shimonoseki Coll. Fish., 12: 229-253.

Bagenal, T.B. and Tesch, P.W., 1978. Age and growth. In: Methods for assessment of fish in fresh waters (ed. T. Benegal), $3^{\text {rd }}$ ed. IBP Handbook No. 3. Blackwell Scientific Publications, Oxford, pp. 101-136.

Brante, A., Fernández, M. and Viard, F., 2011. Microsatellite evidence for sperm storage and multiple paternity in the marine gastropod Crepidula coquimbensis. J. exp. Mar. Biol. Ecol., 396: 83-88. https://doi.org/10.1016/j.jembe.2010.10.001

Chan, S.Y., 2009. The Melongenidae (Mollusca: Gastropoda) of Singapore. Nature in Singapore, 2: 63-67.

Depledge, M.H. and Phillips, D.J.H., 1986. Circulation, respiration and fluid dynamics in the gastropod mollusc, Hemifusus tuba, (Gmelin). J. exp. Mar. Biol. Ecol., 95: 1-13. https://doi.org/10.1016/00220981(86)90083-3

Ferrito, V., Mannino, M.C., Pappalardo, A.M. and Tigano, C., 2007. Morphological variation between Italian populations of Aphanius fasciatus Nardo, 1827 (Teleostei, Cyprinodontidae). J. Fish Biol., 70: 1-20. https://doi.org/10.1111/j.10958649.2006.01192.x

Ge, S. and Hong, D.Y., 1995. Biosystematic studies on Adenophora potaninii Korsh. complex (Campanulaceae) III. Genetic variation and 
taxonomic value of morphological characters. Acta Phytotaxon Sin., 33: 433-443.

Hamada, S., 1974. Growth and feeding of Hemifusus ternatanus in early crawling stage. Japanese $J$. Malacol., 33: 75-79.

Konan, K.M., Adépo-Gourène, A.B., Ouattara, A., Nyingy, W.D. and Gourène, G., 2010. Morphometric variation among male populations of freshwater shrimp macrobrachium vollenhovenii, herklots, 1851 from Côte d'ivoire rivers. Fish. Res., 103: 1-8. https://doi.org/10.1016/j.fishres.2010.01.005

Mamuris, Z., Apostolidis, P., Panagiotaki, P., Theodrou, A.J. and Triantaphyllidisdir, C., 1998. Morphological variation between red mullet populations in Greece. J. Fish Biol., 52: $107-$ 117. https://doi.org/10.1111/j.1095-8649.1998. tb01556.x

Morton, B., 1986a. Reproduction, juvenile growth, consumption and the effects of starvation upon the South China Sea whelk Hemifusus tuba (Gmelin) (Prosobranchia: Melongenidae). J. exp. Mar. Biol. Ecol., 102: 257-280. https://doi.org/10.1016/00220981(86)90181-4

Nie, Z., Wu, H., Wei, J., Zhang, X. and Ma, Z., 2013. Length-weight relationship and morphological studies in Kashgarian loach Triplophysa yarkandensis (Day, 1877) from the Tarim River, Tarim River Basin, North-West china. Indian J. Fish., 60: 15-19.

Obirikorang, K.A., Adjeiboateng, D., Madkour, H.A., Amisah, S. and Otchere, F.A., 2013. Length-weight relationship of the freshwater clam, Galatea paradoxa (Born 1778) from the Volta Estuary, Ghana. Pak. J. biol. Sci., 16: 185-189. https://doi. org/10.3923/pjbs.2013.185.189

Ofori-Danson, P.K. and Amoah, C., 2007. Status of the fishery and culture potential of the Volte Clam, Galatea paradoxa (Born, 1778) in the Lower Volta River. Volta Basin Reseach Project (VBRP) Report, University of Ghana, Legon, pp. 1-25.

Petrakis, G. and Stergiou, K.I., 1995. Weight-length relationships for 33 fish species in Greek water. Fish. Res., 21: 465-469. https://doi.org/10.1016/01657836(94)00294-7

Tang, B., Wei, W., Huang, Y., Zou, X. and Yue, Y., 2016. Growth performance and nutritional composition of Hemifusus ternatanus, under artificial culturing conditions. Aquaculture, 459: 186-190. https://doi. org/10.1016/j.aquaculture.2016.03.051

Tang, B., Yin, F., Gui, C., Chen, X. and Liu, B., 2012. Hatching, growth and hatchling dietary preference in Hemifusus ternatanus, (Gmelin, 1791). Aquaculture, 326: 141-147. https://doi. org/10.1016/j.aquaculture.2011.11.025

Woodcock, S.H. and Benkendorff, K., 2008. The impact of diet on the growth and proximate composition of juvenile whelks, Dicathais orbita (Gastropoda: Mollusca). Aquaculture, 276: 162-170. https://doi. org/10.1016/j.aquaculture.2008.01.036

Xu, Z.C., Wang, C.S. and Zhang, Y.S., 2006. Breeding ecological conditions and propagation habit of Hemifusus ternatanus. J. Fish. China, 30: 848-851.

Vermeij, G.J. and Raven, H., 2009. Southeast Asia as the birthplace of unusual traits: the Melongenidae (Gastropoda) of northwest Borneo. Contrib. Zool., 78: 113-127. https://doi.org/10.1163/1875986607803003 